\title{
A Src inhibitor regulates the cell cycle of human pluripotent stem cells and improves directed differentiation
}

\section{Citation}

Chetty, Sundari, Elise N. Engquist, Elie Mehanna, Kathy O. Lui, Alexander M. Tsankov, and Douglas A. Melton. 2015. "A Src inhibitor regulates the cell cycle of human pluripotent stem cells and improves directed differentiation." The Journal of Cell Biology 210 (7): 1257-1268. doi:10.1083/jcb.201502035. http://dx.doi.org/10.1083/jcb.201502035.

\section{Published Version}

doi:10.1083/jcb.201502035

\section{Permanent link}

http://nrs.harvard.edu/urn-3:HUL.InstRepos:26318710

\section{Terms of Use}

This article was downloaded from Harvard University's DASH repository, and is made available under the terms and conditions applicable to Other Posted Material, as set forth at http:// nrs.harvard.edu/urn-3:HUL.InstRepos:dash.current.terms-of-use\#LAA

\section{Share Your Story}

The Harvard community has made this article openly available.

Please share how this access benefits you. Submit a story.

Accessibility 


\title{
A Src inhibitor regulates the cell cycle of human pluripotent stem cells and improves directed differentiation
}

\author{
Sundari Chetty, ${ }^{1}$ Elise N. Engquist, ${ }^{1}$ Elie Mehanna, ${ }^{1}$ Kathy O. Lui, ${ }^{1}$ Alexander M. Tsankov, ${ }^{1,2}$ and Douglas A. Melton ${ }^{1,3}$ \\ 'Department of Stem Cell and Regenerative Biology, Harvard Stem Cell Institute, Cambridge, MA 02138 \\ 2Broad Institute of MIT and Harvard, Cambridge, MA 02142 \\ 3 Howard Hughes Medical Institute, Harvard University, Cambridge, MA 02138
}

Driving human pluripotent stem cells (hPSCs) into specific lineages is an inefficient and challenging process. We show that a potent Src inhibitor, PP1, regulates expression of genes involved in the G1 to S phase transition of the cell cycle, activates proteins in the retinoblastoma family, and subsequently increases the differentiation propensities of hPSCs into all three germ layers. We further demonstrate that genetic suppression of Src regulates the activity of the retinoblastoma protein and enhances the differentiation potential of hPSCs across all germ layers. These positive effects extend beyond the initial germ layer specification and enable efficient differentiation at subsequent stages of differentiation.

\section{Introduction}

The differentiation propensities of human pluripotent stem cell (hPSC) lines vary from one line to another (Osafune et al., 2008; Bock et al., 2011; Chetty et al., 2013; Gage et al., 2013). Some cell lines fail to yield terminally differentiated cells at subsequent stages of differentiation (Tabar and Studer, 2014). These limitations in the ability to systematically differentiate hPSC lines into desired lineages substantially restrict their utility for cell replacement therapy and disease modeling, as moving stem cell-based therapies to patients will require the ability to differentiate all cell lines.

Here, we show that PP1, a Src tyrosine kinase inhibitor, regulates the retinoblastoma protein $(\mathrm{Rb})$ and cell cycle of hPSCs, enriches cells in the early G1 phase, and improves their multilineage differentiation potential. Importantly, the PP1 treatment yields high differentiation efficiencies even in cell lines that have low differentiation propensities under control conditions. We demonstrate these effects in both human embryonic and induced pluripotent stem cell (iPSC) lines. Furthermore, we show that Src plays an important regulatory role in this process, as genetic suppression of Src regulates $\mathrm{Rb}$ activity and enhances the differentiation potential of hPSCs.

Our focus on PP1 and Src was motivated by the finding that the embryonic cell cycle lengthens to incorporate gap phases as it transitions from a proliferative stage to a stage governed by cell fate decisions (Trelstad et al., 1967; Hartwell and Weinert, 1989; Murray and Kirschner, 1989; Frederick and Andrews, 1994; Edgar and Lehner, 1996). One mechanism that plays a critical role in maintaining cell proliferation

Correspondence to Sundari Chetty: schetty@mcb.harvard.edu; or Douglas A. Melton: dmelton@harvard.edu

Abbreviations used in this paper: hPSC, human pluripotent stem cell; iPSC, induced pluripotent stem cell; qPCR, quantitative PCR; Rb, retinoblastoma protein. at the early developmental stages is Src tyrosine kinase signaling (Frame, 2002; Segawa et al., 2006; Kim et al., 2009). High protein tyrosine kinase activity is required for the early developmental events that occur before cell fate specification (Imamoto and Soriano, 1993; Livingston et al., 1998). Analogous to early development, Src activity is elevated in proliferating PSCs (Annerén et al., 2004), potentially preventing the lengthening of the cell cycle for differentiation and cell fate specification. We therefore hypothesized that inhibiting Src activity might regulate the cell cycle and improve the differentiation propensity of hPSCs.

In previous work, we showed that treatment of hPSCs with DMSO improves differentiation propensity after directed differentiation (Chetty et al., 2013). The present study provides a new tool to improve differentiation and strengthens the case that manipulating the cell cycle is critical for improving directed differentiation. The mechanistic results presented here indicate that Src plays an important regulatory role in controlling cell fate decisions of hPSCs.

\section{Results}

PP1 treatment improves the differentiation capacity of hPSCs in a dose-dependent manner Src-tyrosine kinase signaling regulates cell growth and proliferation of various cell types, including PSCs (Annerén et al., 2004), cancer cells (Frame, 2002), and normal somatic cells

(C) 2015 Chetty et al. This article is distributed under the terms of an AttributionNoncommercial-Share Alike-No Mirror Sites license for the first six months after the publication date (see http://www.rupress.org/terms). After six months it is available under a Creative Commons License (Attribution-Noncommercial-Share Alike 3.0 Unported license, as described at http://creativecommons.org/licenses/by-nc-sa/3.0/). 
A Me<smiles>Cc1ccc(-c2nn(C(C)(C)C)c3ncnc(N)c23)cc1</smiles>

B

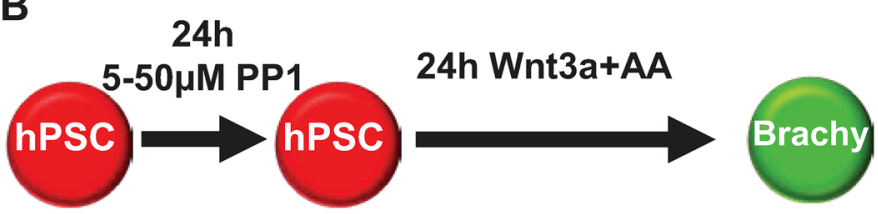

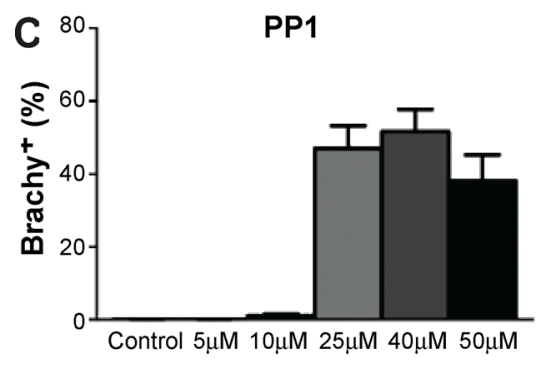

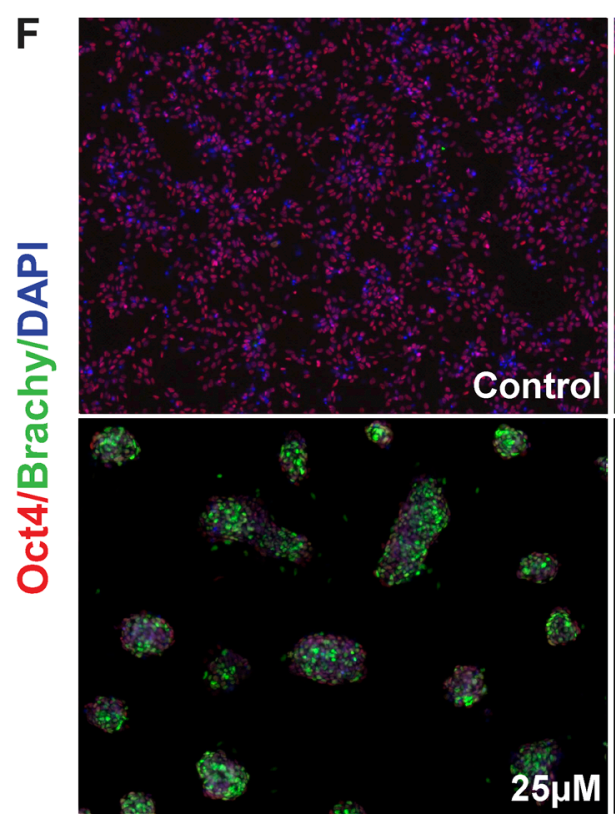

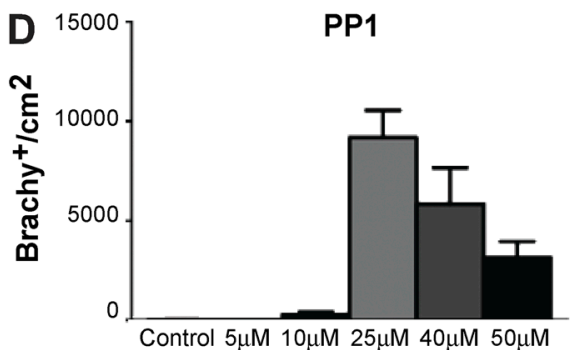
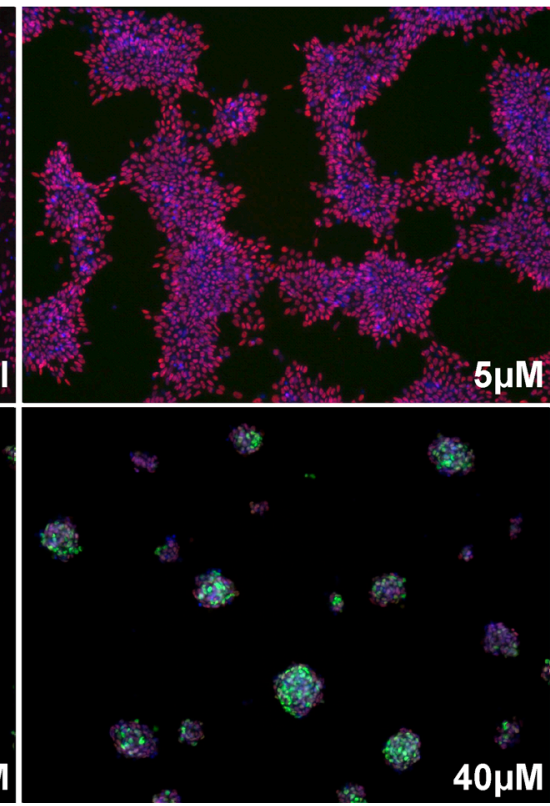
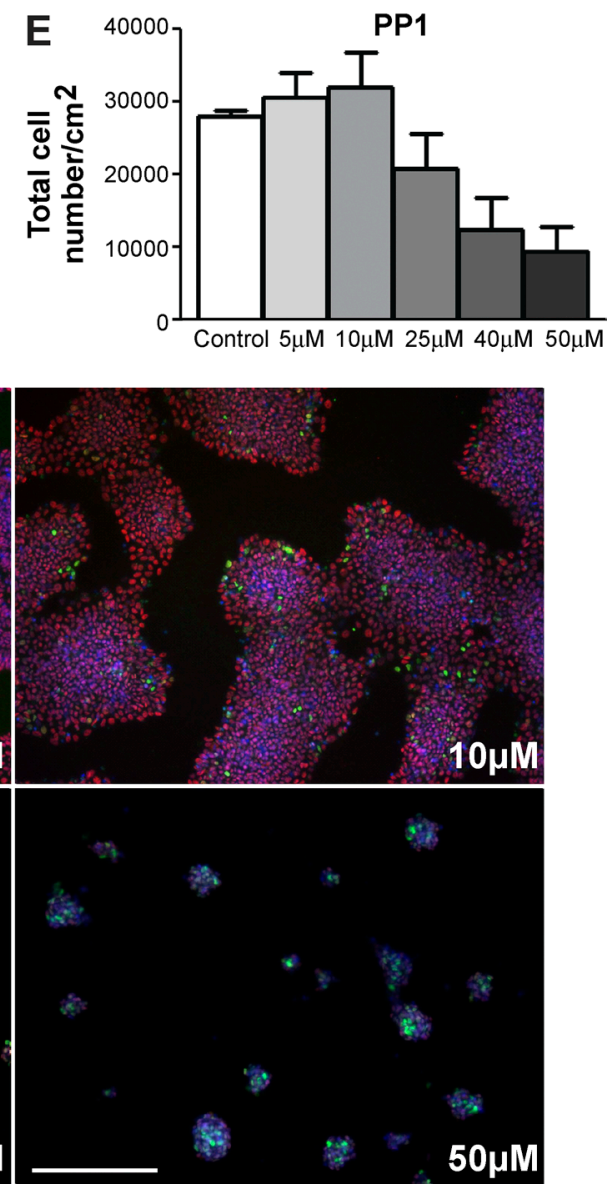

Figure 1. PP1 treatment improves the differentiation capacity of hPSCs in a dose-dependent manner. (A) Chemical structure of 4-amino-5-(4-methylphenyl)7-(t-butyl)pyrazolo-d-3,4-pyrimidine (PP1). (B) Schematic of directed differentiation of hPSCs into Brachy+ cells after no treatment (control) or a 24-h PP1 treatment at varying doses. (C-E) Percentages (C) and absolute numbers (D) of control and PP1-treated HUES6 hPSCs differentiating into Brachy+ cells in relation to the total cell numbers (E) in control and PP1-treated cultures. (F) Immunostaining for Oct4, Brachy, and DAPI in control and PPI-treated cultures after directed differentiation. Error bars indicate SEM of three replicates. Bars, $200 \mu M$.

(Playford and Schaller, 2004). In most cell types, Src is negatively regulated (held in an inactive state), but in PSCs and cancer cells, Src activity is elevated (Frame, 2002; Annerén et al., 2004). PP1 (Fig. 1 A) has been shown to effectively block Src activity and the proliferation of many types of tumorigenic cells (Hanke et al., 1996; Bain et al., 2007). We tested whether inhibition of Src signaling by PP1 treatment affects the differentiation capacity of hPSCs. We focused on the hPSC line HUES6, a cell line with a 24-h doubling time that does not exhibit bias toward any particular lineage and is representative of cell lines with relatively low efficiencies of differentiation (Cowan et al., 2004; Osafune et al., 2008; Bock et al., 2011). To enhance therapeutic utility, differenti- ations were performed under low-serum conditions. After a 24-h treatment with PP1 at different doses, HUES6 cells were cultured in differentiation media with Wnt3a and Activin A for $24 \mathrm{~h}$, then assessed for the percentage of cells that differentiated into Brachyury (Brachy)+ cells, a marker for mesendoderm and an early marker for differentiation (Fig. 1 B).

A 24-h treatment with PP1 increased the percentage as well as the total number of cells that differentiated compared with untreated control cells in a dose-dependent manner (Fig. 1, C-F). At dosages of 25-50 $\mu \mathrm{M}$, the percentage of cells differentiating into Brachy+ cells reached nearly $50 \%$, an $\sim 300$-fold enhancement relative to control cells. In all conditions, cells that did not differentiate retained the 
A
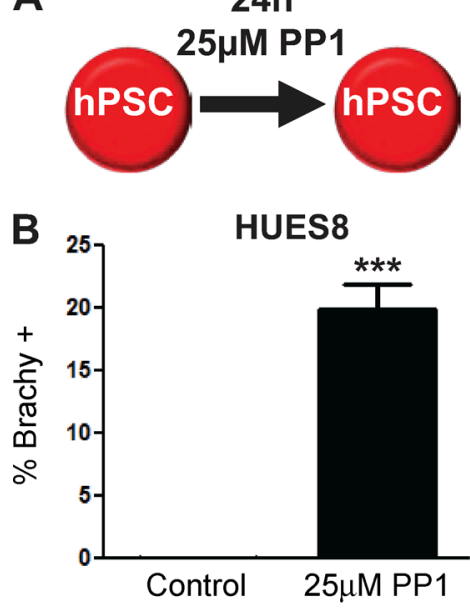

D

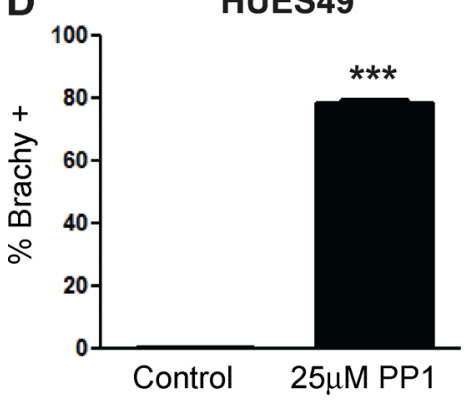

F
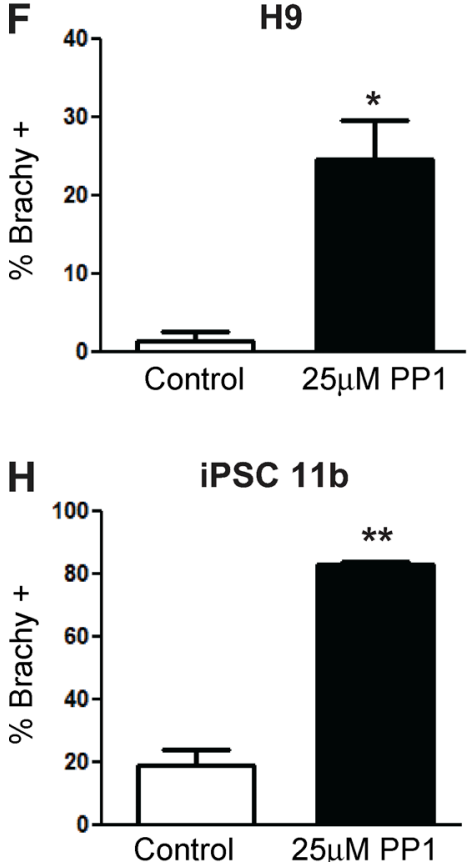

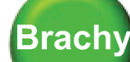

HUES8

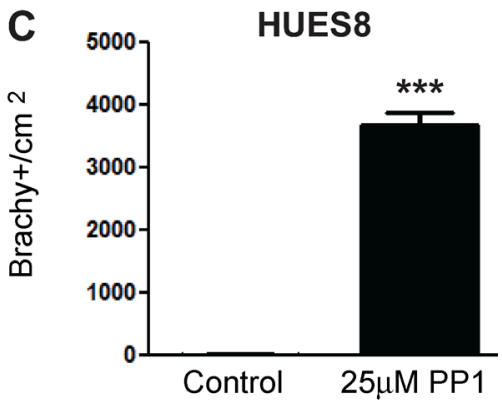

E
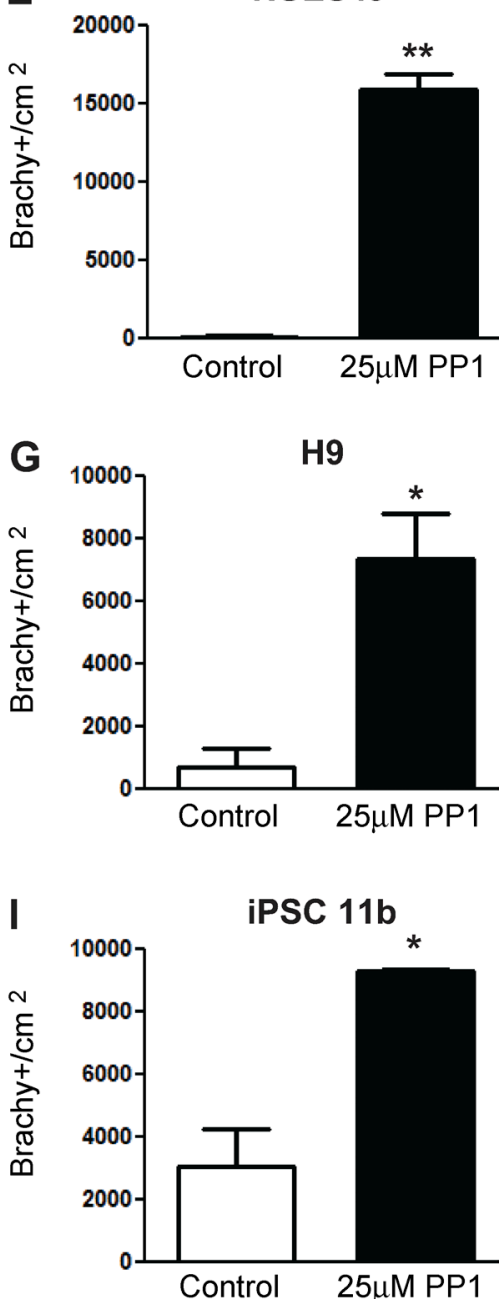

Figure 2. PP1 treatment improves differentiation capacity across hPSC lines. (A) Schematic of directed differentiation of hPSCs into Brachy+ cells after no treatment (control) or a 24-h $25 \mu \mathrm{M}$ PPI treatment. (B-I) Percentages and absolute numbers of control and PPI-treated hPSCs differentiating into Brachy+ cells in the HUES8 (B and C), HUES49 (D and $E), H 9$ ( $F$ and $G$ ), and $P$ PSC $11 \mathrm{~b}(\mathrm{H}$ and I) hPSC lines. Error bars indicate SEM of two replicates (HUES49, $\mathrm{H} 9$, iPSC $11 \mathrm{~b}$ ) or four replicates (HUES8). ${ }^{*}, \mathrm{P} \leq 0.05$; $*$ *, $\mathrm{P} \leq 0.01 ; * * *, \mathrm{P} \leq 0.001$. 
aggregate into tight, dense clusters distinct from the spread-out, planar arrangement of control cells and cells treated with low doses of PP1 (Fig. 1 F).

In addition to dosage, the duration of the PP1 treatment can also regulate the differentiation capacity of hPSCs. Treatment durations that were shorter than the cell line's doubling time induced only a $2-5 \%$ differentiation rate (unpublished data).

Among the inhibitors tested, PP1 proved to be the most effective in enhancing differentiation potential. Consistent with prior reports, treatment of hPSCs with other inhibitors to perturb various cell cycle-related kinase signaling pathways had a minimal or moderate effect on improving differentiation potential (Smith, 2001; Orford and Scadden, 2008; Li and Kirschner, 2014). Treatment with a Cdk2 inhibitor at 5-10 $\mu \mathrm{M}$ induced $\sim 20 \%$ of the cells to differentiate into Brachy+ cells but was associated with a substantial degree of cell loss at higher doses (Fig. S2, A-I).

PP1 treatment regulates the cell cycle and activity of $\mathrm{Rb}$ in hPSCs

Given that the PP1 treatment effectively enhances differentiation potential at the $24 \mathrm{~h}$ time point, we treated hPSCs with $25 \mu \mathrm{M}$ PP1 for $24 \mathrm{~h}$ and investigated the effects on the cell cycle. Cell cycle analysis by flow cytometry showed that the PP1 treatment changes the distribution of hPSCs in the G1, S, and G2/M phases of the cell cycle, increasing the proportion of cells in G1 and decreasing the number of cells in the $\mathrm{S}$ and G2/M phases. These effects were consistently observed in several human embryonic and iPSC lines (Figs. 3, 4 A, and S3). Further investigation of the HUES6 cell line showed that a 24-h treatment with $25 \mu \mathrm{M}$ PP1 nearly doubles the percentage of cells in G1 phase $(\sim 70 \%)$ compared with controls $(\sim 35 \%$; Fig. 4 B). The proportion of cells in the $\mathrm{S}$ and $\mathrm{G} 2 / \mathrm{M}$ phases is concomitantly reduced by at least twofold after the PP1 treatment (Fig. 4 B). A significant shift toward G1 was observed across all cell lines (Fig. 3 and Fig. S3; $\mathrm{P}<0.002$ ).

$\mathrm{Rb}$ predominantly remains in an inactive hyperphosphorylated state throughout the cell cycle of human and mouse PSCs. While phosphorylated Rb promotes cell division, the accumulation of hypophosphorylated $\mathrm{Rb}$ (active $\mathrm{Rb}$ ) is associated with an enrichment of cells in the early G1 phase of the cell cycle and an improved capacity for differentiation (Buchkovich et al., 1989; Chen et al., 1989; Orford and Scadden, 2008). We assessed the phosphorylation status of Rb in control and $25 \mu \mathrm{M}$ PP1-treated hPSCs. After a 24-h PP1 treatment, the percentage of hPSCs expressing hypophosphorylated Rb increased by $>60$-fold from $0.3 \%$ to $20 \%$ (Fig. 4, C and D). Phosphorylation of $\mathrm{Rb}$ occurs at 16 distinct sites (Harbour and Dean, 2000). Assessment of the inactive phosphorylated status of $\mathrm{Rb}$ at one of these sites (serine 780) showed that PP1 treatment leads to a twofold reduction in the percentage of cells expressing pRb780 (Fig. 4, C and E). The phosphorylation of $\mathrm{Rb}$ at serine 780 was also differentially regulated by other cell cycle inhibitors (Fig. S2 J).

In its hypophosphorylated state, Rb plays a critical role in growth suppression. In coordination with $\mathrm{Rb}$, the retinoblastoma-associated protein 46/48 (RbAP46/48; a histone chaperone protein) regulates the cell cycle by aiding in the transcriptional repression of Rb-related target genes, particularly genes involved in the G1 to S phase transition (Harbour and Dean, 2000; Taylor-Harding et al., 2004). We assessed the fraction of cells expressing the cofactor RbAP46/48 in
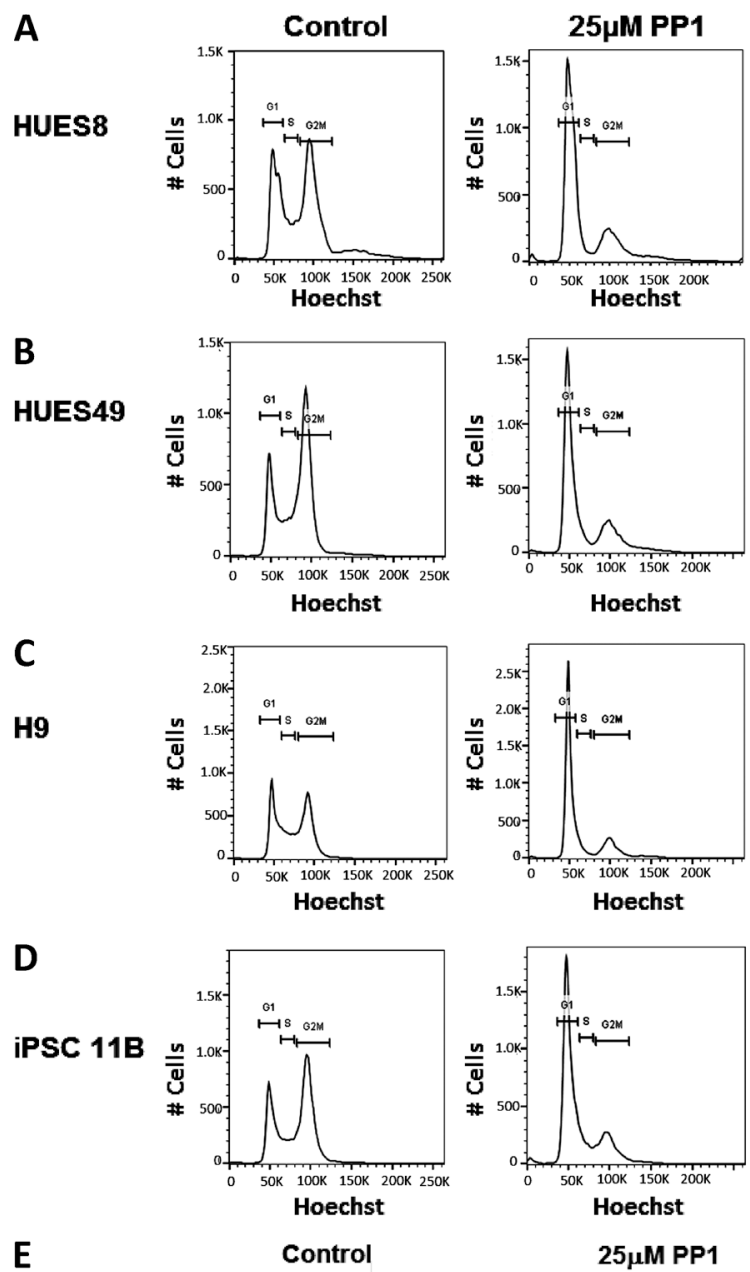

$\mathbf{E}$
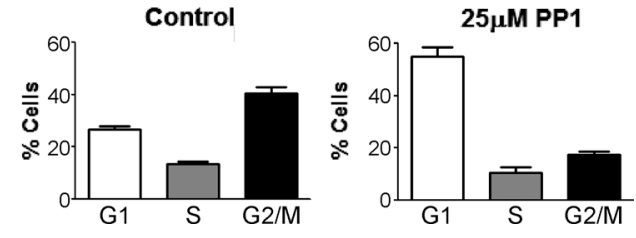

Figure 3. PP1 treatment enriches cells in G1 across hPSC lines. Distribution of hPSCs in the G1, S, and G2/M phases of the cell cycle after no treatment (control) or a 24 -h $25 \mu \mathrm{M} \mathrm{PPI}$ treatment in the HUES8 (A), HUES49 (B), H9 (C), and iPSC $11 \mathrm{~b}(\mathrm{D}) \mathrm{hPSC}$ lines. (E) Mean percentage of hPSCs across all cell lines in the G1, S, and G2/M phases of the cell cycle after no treatment (control) or a 24-h $25 \mu M$ PP1 treatment.

control and PP1-treated hPSCs. Flow cytometry analysis showed that the percentage of hPSCs expressing RbAP46/48 nearly doubles between control and PP1-treated cells (Fig. 4, $\mathrm{F}$ and $\mathrm{G})$. Furthermore, treatment with $25 \mu \mathrm{M}$ PP1 for $24 \mathrm{~h}$ also regulated the expression of many genes associated with cell cycle control. The expression of genes promoting cell division, including Cyclin $A 1, C d k 2$, and $C d c 6$, were significantly reduced in PP1-treated hPSCs relative to control cells (Fig. $4 \mathrm{H}$ ). Expression of p27, a cell cycle inhibitor that promotes growth arrest in G1 (Toyoshima and Hunter, 1994), was significantly increased in PP1-treated hPSCs compared with control cells (Fig. $4 \mathrm{H}$ ). No significant difference in expression levels was observed for Cyclin A2, Cyclin D1, Cyclin E1, E2f1, and $p 21$ between control and PP1-treated hPSCs (Fig. $4 \mathrm{H}$ ). Together, these results show that PP1 treatment of hPSCs promotes growth inhibition and an accumulation of 


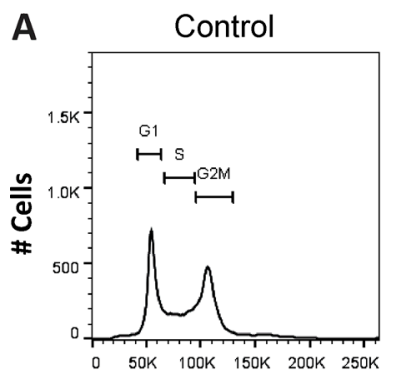

Hoechst

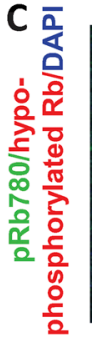

$25 \mu \mathrm{M}$ PP1

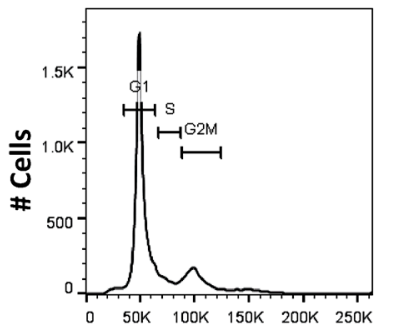

Hoechst
B
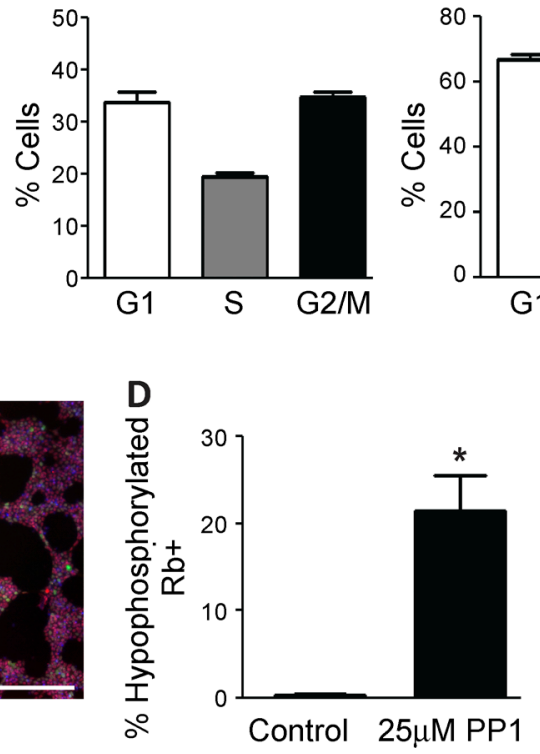

$25 \mu \mathrm{M}$ PP1

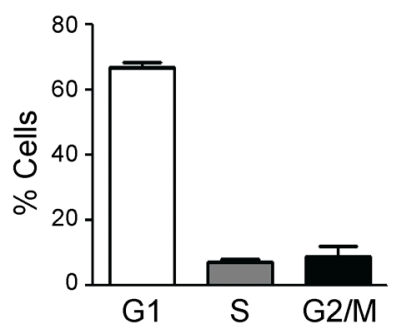

E

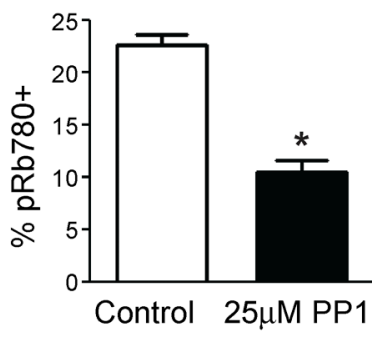

$\mathbf{F}$

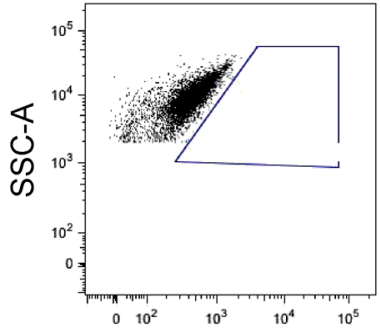

Control

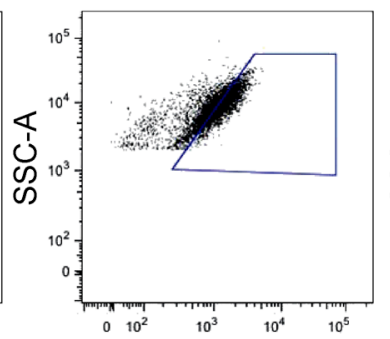

PP1

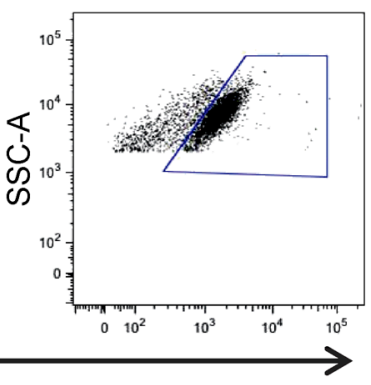

G

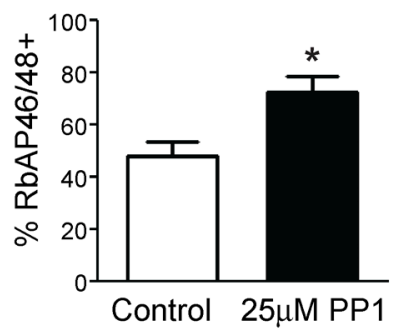

RbAp46/48

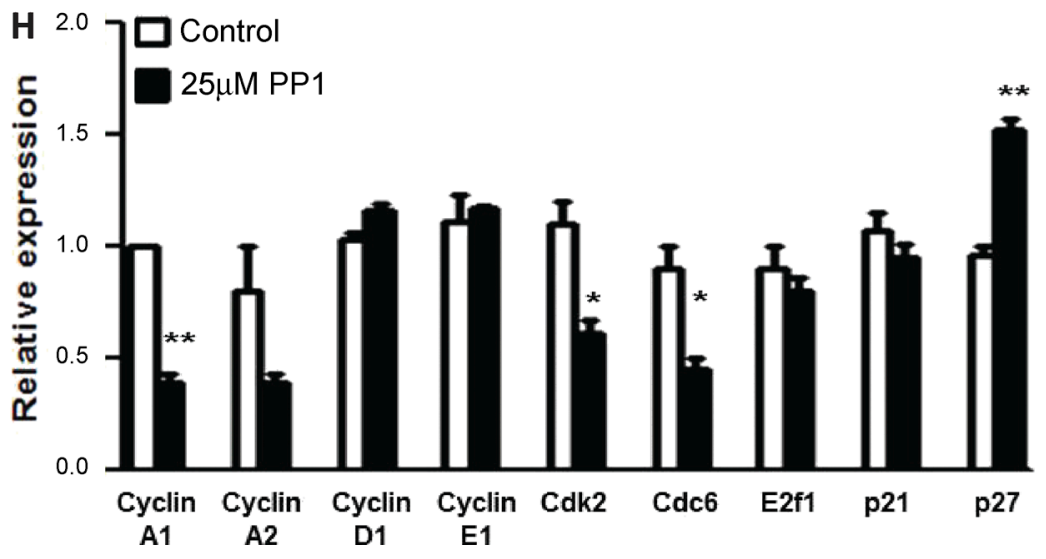

Figure 4. PP1 treatment regulates the cell cycle and enhances the activity of Rb in hPSCs. (A and B) Distribution (A) and percentage (B) of HUES6 hPSCs in the G1, S, and G2/M phases of the cell cycle after no treatment (Control) or a 24-h $25 \mu M$ PP 1 treatment. (C) Immunostaining for the active hypophosphorylated Rb (red) and inactive phosphorylated pRb780 (green) in control and PP1-treated hPSCs. Bar, $200 \mu \mathrm{M}$. (D and E) Percentage of hPSCs expressing hypophosphorylated $\mathrm{Rb}(\mathrm{D})$ and hyperphosphorylated $\mathrm{Rb}(\mathrm{E} ; \mathrm{pRb} 780)$ after no treatment (Control) or a 24-h $25 \mu \mathrm{M} \mathrm{PP1}$ treatment. (F and G) Flow cytometry analysis of the percentage of hPSCs expressing the retinoblastoma-associated protein 46/48 (RbAP46/48) after no treatment (Control) or a 24 -h $25 \mu M$ PP1 treatment. (H) Relative expression levels of cell cycle-regulated genes in PP1-treated hPSCs compared with untreated controls. Error bars indicate SEM of $2-3$ replicates. ${ }^{*}, \mathrm{P} \leq 0.05 ;{ }^{*}, \mathrm{P} \leq 0.01$.

cells in the G1 phase by regulating genes involved in the G1 to $S$ phase transition. The enhanced hypophosphorylated state of $\mathrm{Rb}$ increases the proportion of cells in the early G1 phase and more generally indicates an increased presence of early G1 in the hPSC cycle after PP1 treatment.
Genetic suppression of Src regulates $\mathbf{R b}$ activity and improves the differentiation capacity of hPSCs across all germ layers Given that PP1 is a potent Src inhibitor (Hanke et al., 1996; Bain et al., 2007), we assessed whether treatment of hPSCs with 
PP1 reduced protein levels of Src. Western blot analysis using two different Src specific antibodies showed that PP1 treatment does indeed suppress Src levels (Fig. 5 A). To investigate whether suppression of Src mimics the effects of PP1 on hPSCs, we next genetically suppressed Src in hPSCs using siRNA. siRNA-mediated knockdown of Src suppressed both the gene expression (Fig. 5 B) and protein (Fig. 5 C) levels of Src in hPSCs. Similar to PP1, Src knockdown also enhanced the activity of $\mathrm{Rb}$ by substantially reducing the levels of the phosphorylated and hyperphosphorylated forms of the Rb protein ( $\mathrm{ppRb}$ ) and increasing levels of the hypo- or underphosphorylated forms of $\mathrm{Rb}$ (Fig. 5 C). Together with PP1, these results provide further support that inhibition of Src increases the proportion of hPSCs in the early G1 phase of the cell cycle.

Prior literature has shown that cells have an enhanced capacity to respond to extracellular signals in the G1 phase (Scott et al., 1982). To investigate whether these effects regulate the differentiation propensity of hPSCs, we next assessed whether genetic suppression of Src improves the differentiation potential of hPSCs across all germ layers. After Src knockdown of hPSCs with siRNA, we subsequently induced differentiation into each of the germ layers using three different directed differentiation protocols (Chetty et al., 2013; Fig. 5 D). The percentage of cells becoming Sox1+, Brachy+, and Sox17+ cells was quantified to assess multilineage differentiation potential into the ectodermal, mesodermal, and endodermal germ layers, respectively (Fig. 5 D). Transfection of hPSCs with Src siRNA before directed differentiation significantly increased the number and percentage of differentiated cells across all three germ layers (Fig. 5, E and F). After Src knockdown, the percentage of hPSCs that differentiated into each germ layer was enhanced by $\sim 2-10$-fold (Fig. 5 F). At the time points assessed, differentiation rates of $\sim 50 \%$ were observed across all the germ layers after Src knockdown (Fig. 5 F). While Src knockdown promoted aggregation of cells initially, the cells spread out more rapidly after differentiation compared with the PP1 treatment. The suppression of the protein expression of Src was also reduced to a greater degree in PP1-treated cultures compared with genetic suppression of Src, potentially due to variations in potency and/ or technical limitations of using siRNA (Fig. 5, A and C).

PP1 treatment improves the differentiation capacity of hPSCs across all germ layers

Similar to Src knockdown, we next tested whether the PP1 treatment improves the differentiation potential of hPSCs across germ layers. We treated HUES6 hPSCs with $25 \mu \mathrm{M}$ PP1 for $24 \mathrm{~h}$ and subsequently induced differentiation into each of the germ layers (Fig. S4 A). The percentage of cells becoming Pax6+, Brachy+, and Sox17+ cells was quantified to assess multilineage differentiation potential into the ectodermal, mesodermal, and endodermal germ layers, respectively (Fig. S4 A). Treatment of hPSCs with $25 \mu \mathrm{M}$ PP1 for $24 \mathrm{~h}$ before directed differentiation significantly increased the number and percentage of differentiated cells across all three germ layers (Fig. S4, B and C). No significant differences in total cell number were observed for differentiations toward the ectodermal and endodermal germ layers. A 1-d differentiation toward the mesodermal germ layer resulted in a reduction in total cell number after the PP1 treatment. After PP1 treatment, the percentage of hPSCs that differentiated into each germ layer was enhanced by $\sim 10$-fold for ectodermal differentiation, 60-fold for mesodermal differentiation, and 2.5-fold for endodermal differentiation
(Fig. S4 C). At the time points assessed, differentiation rates of $40-75 \%$ were observed across all the germ layers after the PP1 treatment, roughly comparable to the differentiation rates observed for genetic suppression of Src (Fig. 5). Differences in these rates between the PP1 treatment and genetic suppression of Src could be due to variations in the potency of the treatments.

To further evaluate how well stem cells differentiate into the three germ layers after the PP1 treatment, we used the highly quantitative PCR (qPCR)-based Scorecard assay as an assessment of lineage specification (Bock et al., 2011). Three published directed differentiation protocols were used to differentiate hPSCs into representative populations of the ectodermal (dEC), mesodermal (dME), and endodermal (dEN) germ layers (Gifford et al., 2013; Fig. 6 A). The expression levels of a panel of genes specific to pluripotent stem cells and the three germ layers were measured in control and PP1-treated hPSCs and differentiated cultures. For most germ layer markers, higher expression levels were observed in PP1-treated differentiated cells compared with controls (Fig. 6 B). The mean expression across all ectodermal, mesodermal, and endodermal markers on the panel was also significantly higher in PP1-treated differentiated cells relative to controls (Fig. 6 B, right bars). These differences were generally not present in PP1-treated and control hPSCs before directed differentiation (Fig. S4 D). In comparison to a reference set of 14 other pluripotent stem cell lines, the PP1treated differentiated cells had a higher germ layer differentiation potential than control samples (Fig. S4, E and F) and often had higher potential than other cell lines in the reference set.

These results show that the PP1 treatment improves lineage specification after directed differentiation by enhancing the expression of genes relevant for a given lineage. Together, these analyses show that the PP1 treatment improves the capacity for differentiation using six different induction protocols.

Improvements in lineage specification would predict that the PP1 effects should persist to improve differentiation at subsequent stages of differentiation. To evaluate the long-term effects of PP1, hPSCs were differentiated through a 15-d directed differentiation protocol into Pdx1+ pancreatic progenitor cells after the initial 24-h $25 \mu \mathrm{M}$ PP1 treatment (Fig. 6 C). The PP1 treatment of hPSCs increased the number of Pdx1+ cells by threefold, inducing a 70\% differentiation rate (Fig. 6, D and E). The PP1-treated cells also continued to expand throughout the stages of the directed differentiation protocol (Fig. 6 F). Further differentiation of the PP1-treated hPSCs toward terminally differentiated cells of the pancreatic lineage (Fig. S5 A) promoted differentiation into Nkx6.1+ and Ngn3+ endocrine cells as well as hormone-expressing C-peptide+ cells (Fig. S5 B). Thus, the increased differentiation efficiency after PP1 treatment is sustained throughout subsequent stages of differentiation and shows that the PP1 treatment is capable of driving hPSCs past the initial germ layers toward later stages of development.

In prior work, we showed that pretreatment with DMSO at a concentration of 1-2\% could significantly improve the differentiation propensities of hPSCs (Chetty et al., 2013). We tested whether combining PP1 and DMSO could have beneficial effects on hPSC differentiation. While combining the two treatments (25 $\mu \mathrm{M}$ PP1 with $2 \%$ DMSO) simultaneously compromised cell survival (unpublished data), sequential treatment with a lower concentration of DMSO $(0.5 \%)$ had positive effects. After a 24-h treatment with $25 \mu \mathrm{M}$ PP1, hPSCs were treated with $0.5 \%$ DMSO for $24 \mathrm{~h}$ and then cultured in differentiation media with Wnt3a and Activin A for $24 \mathrm{~h}$ (Fig. S5 C). This com- 
A

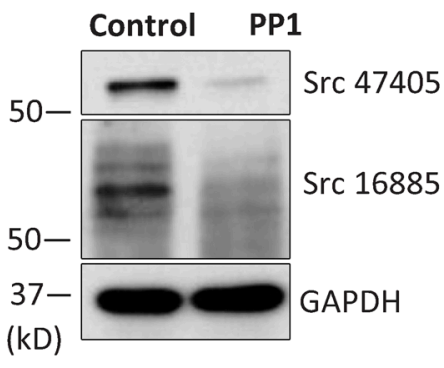

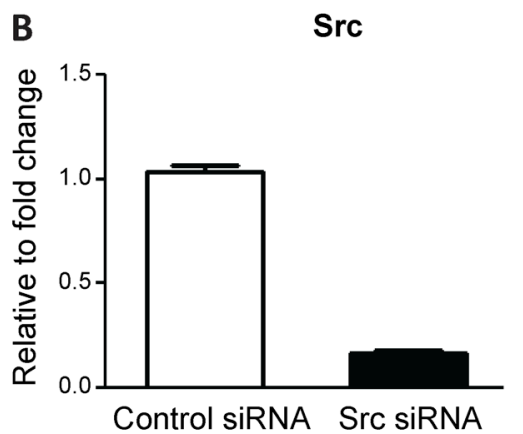

D

Ectoderm

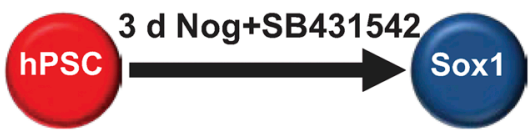

E
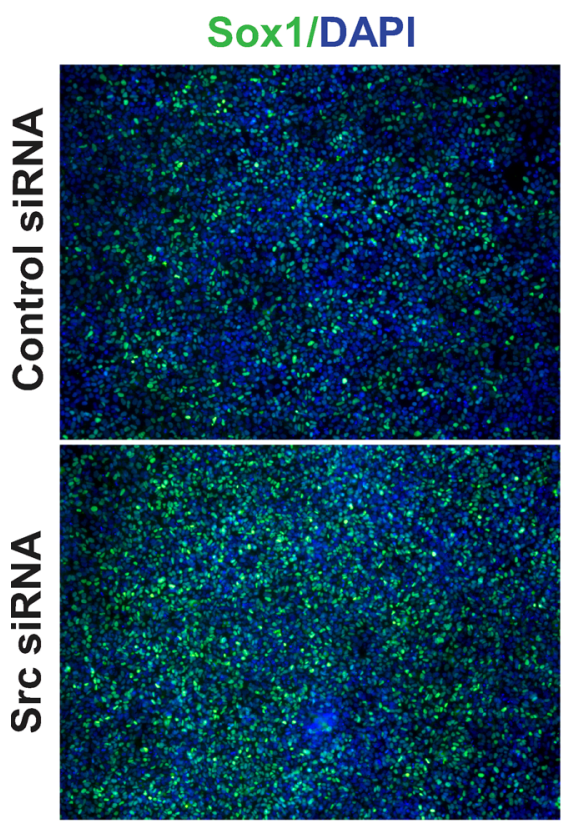

F

Ectoderm

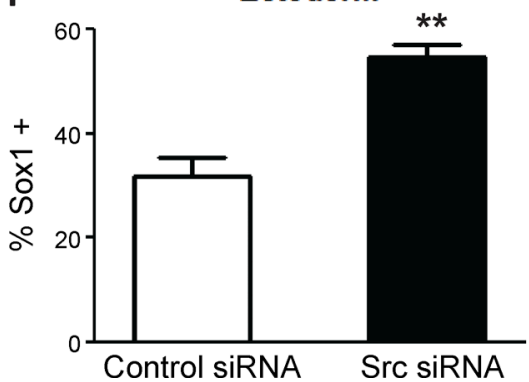

Mesoderm

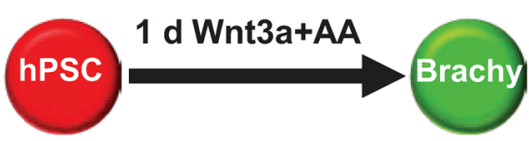

Mesoderm

Brachy/DAPI
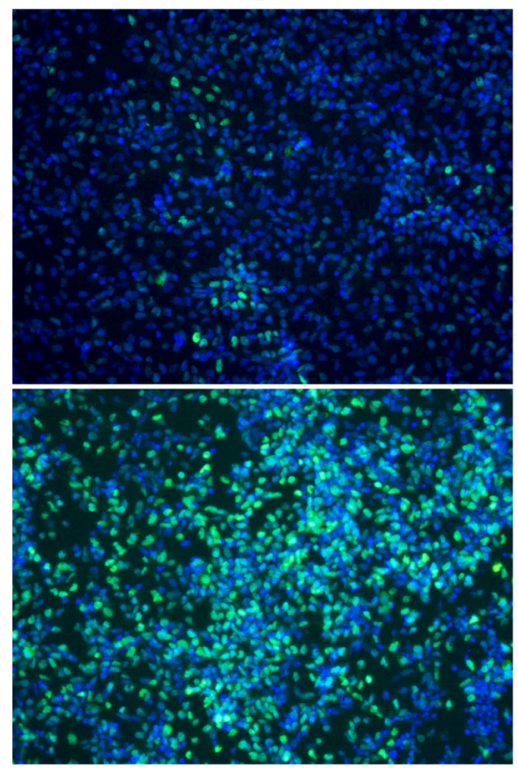

Mesoderm

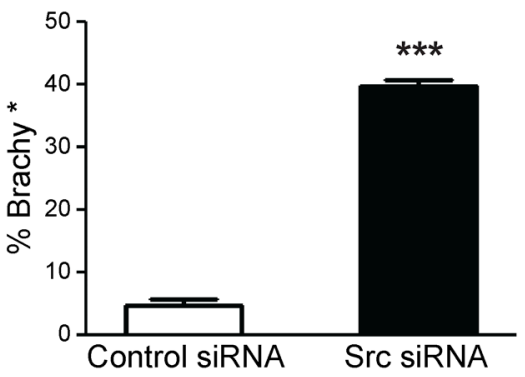

C Control Src SIRNA SIRNA

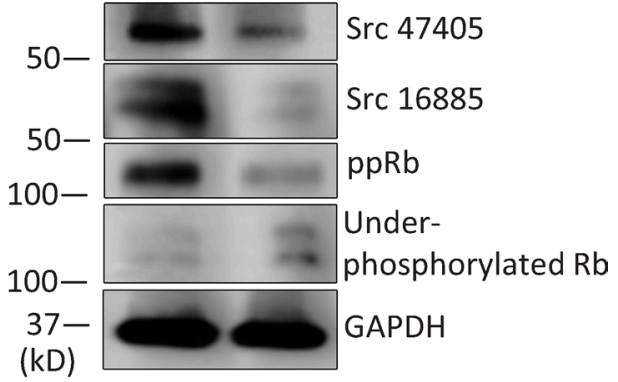

Endoderm

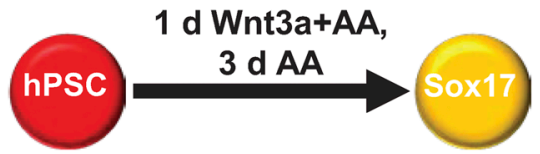

\section{Endoderm}

Sox17/DAPI
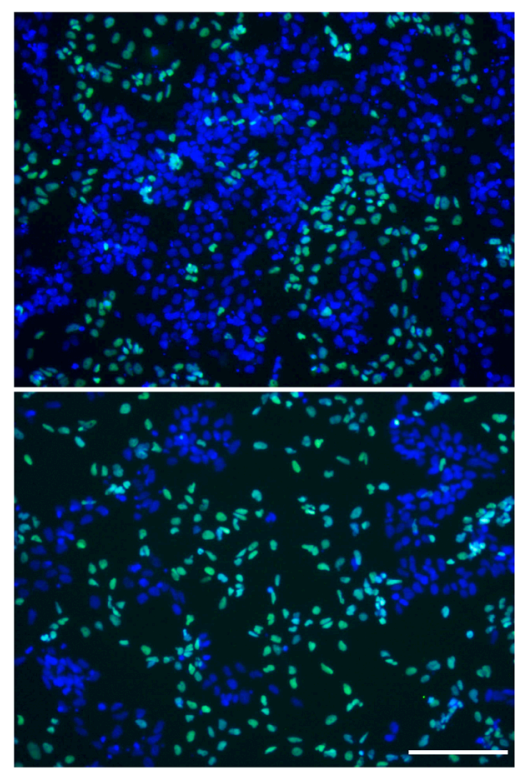

Endoderm

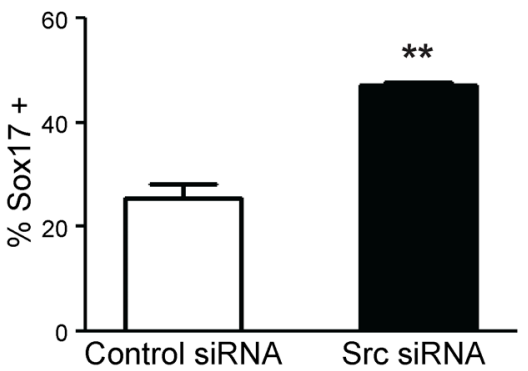

Figure 5. Genetic suppression of Src regulates the activity of Rb and improves the differentiation capacity of hPSCs across all germ layers. (A) Western blot with Src-specific antibodies shows the levels of the Src protein after PP1 treatment of hPSCs. (B) Relative expression level of the Src gene in hPSCs transfected with Src siRNA compared with hPSCs transfected with nontargeting control siRNA. (C) Western blot with Src-specific antibodies shows the levels of the Src protein in hPSCs transfected with Src siRNA; phospho-specific antibodies show the levels of the indicated phosphorylated forms of Rb after transfection with Src siRNA. ppRb, hyperphosphorylated Rb. (D) Schematic of directed differentiation of hPSCs into Sox l+ ectodermal, Brachy+ mesodermal, or Sox 17+ endodermal cells after transfection of hPSCs with control siRNA or Src siRNA. (E) Immunostaining for the indicated differentiation markers after directed differentiation in control and Src siRNA-transfected cultures. Bar, $200 \mu \mathrm{M}$. (F) Percentages of cells expressing the indicated differentiation markers in control and Src siRNA-transfected cultures. Error bars indicate SEM of 2-3 replicates. **, P $0.01 ; * * *, P \leq 0.001$. 
A

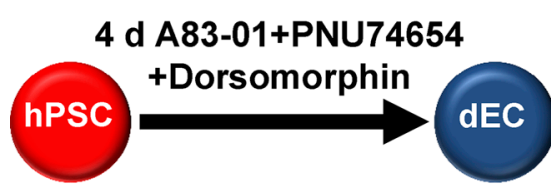

B

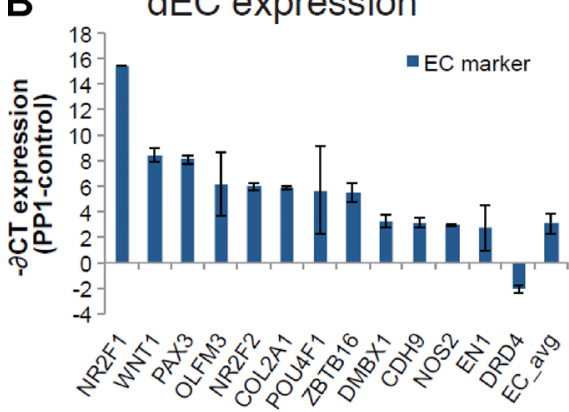

Mesoderm

$1 \mathrm{~d} \mathrm{AA}, 3 \mathrm{~d}$ BMP4

+VEGF+FGF2

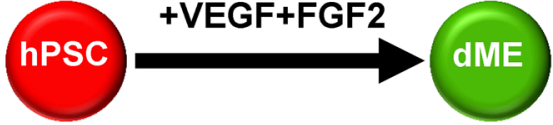

$\mathrm{dME}$ expression

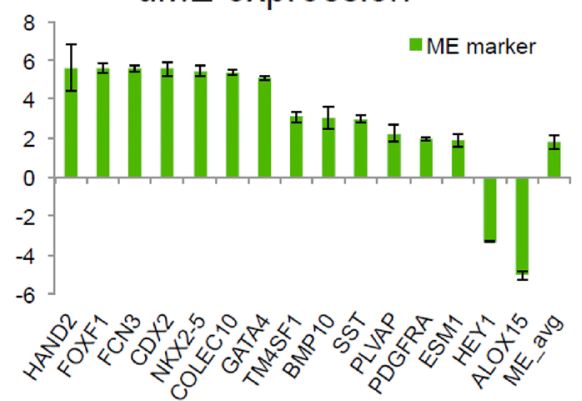

Endoderm

4 d LiCl+AA

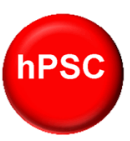

dEN expression

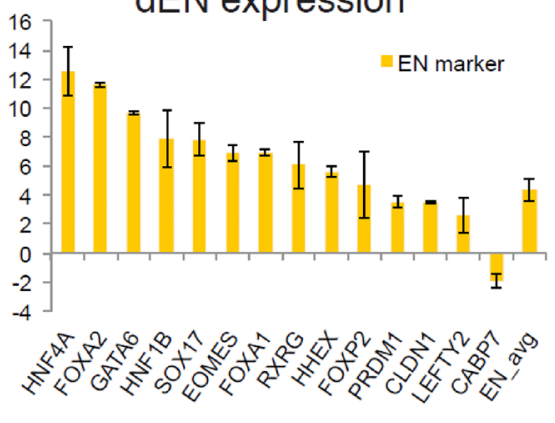

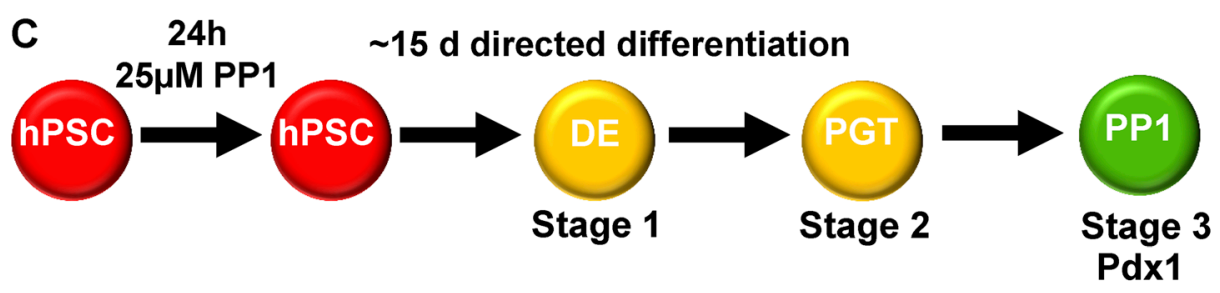

D
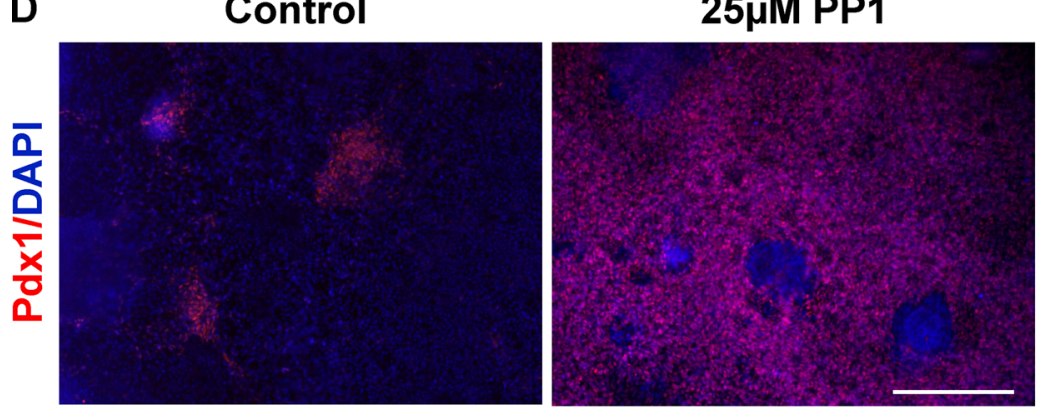

E

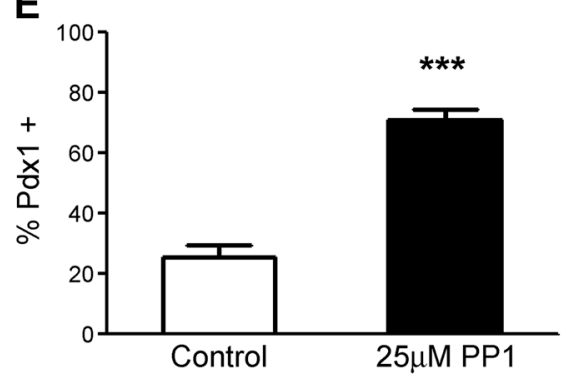

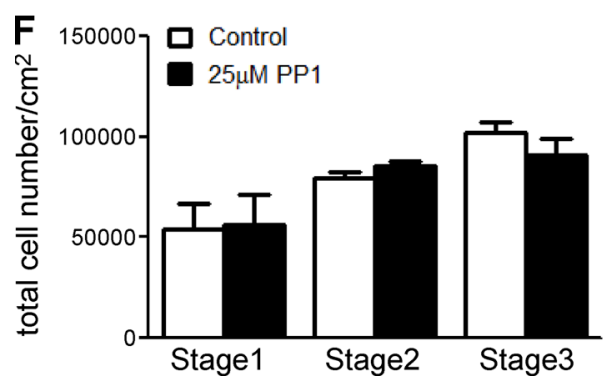

Figure 6. PP1 treatment improves the specificity of differentiation of hPSCs. (A) Schematic of directed differentiation of HUES6 hPSCs into ectoderm (dEC, blue), mesoderm ( $\mathrm{dME}$, green), and endoderm ( $\mathrm{dEN}$, yellow) populations. (B) Difference in mean expression between PP1-treated and control samples, $-\partial C T=-\left(C_{P P 1}-C_{C O N T R O L}\right)$, for selected ectoderm (left), mesoderm (center), and endoderm (right) marker genes after directed differentiation into the three germ layers. All markers with $-\partial \mathrm{CT} \geq 1.9$ or $\leq-1.9$ are displayed, where $-\partial \mathrm{CT}=2$ represents a fourfold increase in expression for PP 1 -treated versus control samples. The mean difference in expression for all ectoderm, mesoderm, and endoderm markers on the Scorecard panel (Life Technologies) is displayed as the rightmost bar. Error bars indicate standard deviation in difference in expression of two replicates. (C) Schematic of stepwise differentiation into pancreatic progenitor (PPl; $\mathrm{Pdxl}+$ ) cells following a 15-d directed differentiation protocol after no treatment (control) or a $24-\mathrm{h} 25 \mu \mathrm{M} P P 1$ treatment. (D) Immunostaining for Pdxl in control and PPl-treated cultures after directed differentiation. Bar, $200 \mu M$. (E) Percentage of cells differentiating into Pdx l+ pancreatic progenitor cells in control and PP1-treated cultures. (F) Total cell numbers in control and PP1-treated cultures through the three stages of directed differentiation. Error bars indicate SEM of 4-6 replicates. ***, P $\leq 0.001$.

bined treatment increased the percentage and absolute number of Brachy+ cells relative to cultures treated with PP1 alone in the HUES 6 line (Fig. 1 and Fig. S5, D-F). The combined treat- ment increased the absolute yield of differentiated cells in other cell lines as well (Fig. S5 G). These findings indicate that optimizing the concentrations and timing of the DMSO and PP1 
treatments could provide further benefits for directed differentiation. Using different doses of these two treatments at various stages of directed differentiation could also improve long-term differentiation potential and should be further explored.

\section{Discussion}

In summary, the results show that a potent Src inhibitor, PP1, regulates the cell cycle and differentiation capacity of both human embryonic and iPSCs. A 24-h treatment with PP1 modulates the expression of genes involved in the G1 to $S$ phase transition, enhances $\mathrm{Rb}$ activity, and increases the percent of cells in the early G1 phase of the cell cycle. After these effects, hPSCs respond more efficiently and effectively to various directed differentiation protocols, leading to improvements in differentiation potentials across all germ layers. Genetic suppression of Src in hPSCs similarly activates Rb and improves differentiation capacity, suggesting an important role for Src in controlling proliferation and differentiation. These early manipulations of the starting state of hPSCs increase the output and specificity of differentiated cells at subsequent stages. The PP1 treatment enhances the yield of differentiated cells to $80 \%$ even in cell lines that would otherwise have low differentiation propensities. In cases where efficiencies are already high under control conditions, PP1 has no adverse effects. Thus, the effects are durable in that they extend beyond the initial germ layer specification.

Our findings on the importance of the cell cycle mirror results in the literature on embryogenesis. In early development as well as in pluripotent stem cells, a truncated cell cycle initially supports the amplification of cells (Smith, 2001; Orford and Scadden, 2008). However, the cell cycle then lengthens as development progresses to incorporate gap phases and give cells the opportunity to become more specialized (Trelstad et al., 1967; Hartwell and Weinert, 1989; Murray and Kirschner, 1989; Frederick and Andrews, 1994; Edgar and Lehner, 1996). Similarly, lengthening the truncated cell cycle of pluripotent stem cells through suppression of Src or small molecules such as PP1 may help direct their differentiation into specialized cell types.

Few factors have been identified to date that effectively regulate the pluripotent cell cycle and directed differentiation (Smith, 2001; Orford and Scadden, 2008; Zhu et al., 2009; Chetty et al., 2013; Li and Kirschner, 2014). PP1 has proven to be a potent tool to regulate the pluripotent G1 phase, as it enhances the hypophosphorylated state of $\mathrm{Rb}$ and enriches cells in the early G1 phase before directed differentiation. Our findings also support recent work suggesting that the G1 phase of the cell cycle may play an important role in enhancing the differentiation of hPSCs (Sela et al., 2012; Pauklin and Vallier, 2013; Singh et al., 2013). Given its role in regulating Rb and the cell cycle, PP1 could also be a useful tool in controlling the tumorigenicity of pluripotent stem cells and their differentiated progeny to enhance their therapeutic utility (Ben-David and Benvenisty, 2011).

The robust impacts of the PP1 treatment and genetic suppression of Src on hPSCs are consistent with prior work showing the importance of Src tyrosine kinase activity in regulating cell proliferation in early development (Trelstad et al., 1967; Frederick and Andrews, 1994). In addition, with the evolution of multicellular organisms, a negative regulation of Src was acquired that proved to be critical for interactions and communications between cells (Segawa et al., 2006). Src inhibition may similarly play an important regulatory role as a single cell undergoes cell division into a multicellular organism in early development.

More broadly, this study shows that the PP1 treatment alters the "starting state" of hPSCs to be more amenable to directed differentiation. Manipulating this starting state, whether through PP1, direct inhibition of Src, or other tools, increases the utility of pluripotent stem cells. Studying how this state relates to the recently established primitive "reset" state of hPSCs (Takashima et al., 2014) could provide further mechanistic insights into how various pluripotent states control cell fate decisions and the developmental potential of pluripotent stem cells.

\section{Materials and methods}

\section{hPSC maintenance conditions}

All hPSC cultures were maintained at $37^{\circ} \mathrm{C}, 5 \% \mathrm{CO}_{2}$ and grown on a monolayer of irradiated CF1 mouse embryonic fibroblasts (MEFs; GlobalStem) in hPSC medium consisting of KO-DMEM (Invitrogen), 10\% KOSR (Invitrogen), 1\% GlutaMAX, nonessential amino acids, penicillin/streptomycin, and $0.1 \% \beta$-mercaptoethanol supplemented with $10 \mathrm{ng} / \mathrm{ml} \mathrm{bFGF}$ (Invitrogen). Medium was changed every $24 \mathrm{~h}$, and lines were passaged using TrypLE (Invitrogen). Before differentiation experiments, cells were expanded for at least two passages on Matrigel (BD) in mTeSR (STEMCELL Technologies) with $10 \mu \mathrm{M}$ of ROCK inhibitor Y-27632 (Abcam).

The HUES cell lines (HUES6, HUES8, HUES49, and H9; Cowan et al., 2004; Osafune et al., 2008) and the iPSC line (iPSC11b; Boulting et al., 2011) were used in this study.

siRNA transfection. Src siRNA (s13414, Life Technologies; Chr. 20: 35973088-36033821) and nontargeting control siRNA (4390843; Life Technologies) were transfected into hPSCs plated onto Matrigel-coated plates at $70 \%$ confluence. Cells were transfected with either control siRNA (50 pmol) or Src siRNA (50 pmol) using Lipofectamine RNAimax transfection reagent (Invitrogen), according to the manufacturer's instructions. Cells were subsequently either differentiated or collected for analysis $24 \mathrm{~h}$ after transfection.

\section{Differentiation protocols}

For all differentiation studies, hPSCs were plated onto wells coated with growth factor-reduced Matrigel (BD) in mTeSR with $10 \mu \mathrm{M}$ ROCK inhibitor Y-27632. Cells were plated at a density of 1-2 million per well of a six-well plate or 100,000-200,000 per well of a 96-well plate. $24 \mathrm{~h}$ before the onset of differentiation, cells were cultured in mTeSR with inhibitor treatment. Inhibitor medium was removed after $24 \mathrm{~h}$ and replaced with differentiation-inducing media at the start of each differentiation, with replacement of medium every day in all protocols.

Treatments in this study include PP1 (Thermo Fisher Scientific), PP2 (Tocris Bioscience), 1-Naphthyl PP1 (Tocris Bioscience), Saracatinib (Thermo Fisher Scientific), Bosutinib (Sigma-Aldrich), K252a (Sigma-Aldrich), $N$-[(2R)-2,3-Dihydroxypropoxy]-3,4-difluoro-2-[(2-fluoro-4-iodophenyl)amino]-benzamide (Stemgent), Roscovitine (Sigma-Aldrich), CDK2 inhibitor (EMD Millipore), and Palbociclib $\mathrm{HCl}$ (Selleck Chemicals) at dosages of $1 \mu \mathrm{M}, 5 \mu \mathrm{M}, 10 \mu \mathrm{M}$, $25 \mu \mathrm{M}, 40 \mu \mathrm{M}$, and $50 \mu \mathrm{M}$ for $24 \mathrm{~h}$.

To induce differentiation into the ectodermal, mesodermal, and endodermal germ layers and pancreatic endocrine lineage, cells were directly differentiated as follows.

Ectoderm. Cells were cultured in KO-DMEM (Invitrogen) medium containing 10\% knockout serum replacement (Invitrogen) and supplemented with Noggin (500 ng/ml; R\&D Systems) and 
4-[4-(1,3-benzodioxol-5-yl)-5-(2-pyridinyl)-1H-imidazol-2-yl]benzamide (10 $\mu \mathrm{M}$; Tocris) for 3-4 d.

Mesoderm. Cells were cultured in Advanced RPMI 1640 (reduced serum; Invitrogen) or RPMI 1640 medium (Invitrogen) supplemented with human recombinant AA (100 ng/ml) + Wnt3a (20 ng/ml; R\&D Systems) for $1 \mathrm{~d}$.

Endoderm. Cells were cultured in MCDB-131 medium (Invitrogen) supplemented with $\mathrm{NaHCO}_{3}(2.5 \mathrm{~g} /$ liter $), 1 \%$ GlutaMAX, glucose (5.5 mM), 0.1\% FAF-BSA (Proliant/Lampire), and ITS:X (1:50,000; Invitrogen), and treated with Wnt $3 \mathrm{a}(20 \mathrm{ng} / \mathrm{ml})+\mathrm{AA}(100 \mathrm{ng} / \mathrm{ml})$ for 1 $\mathrm{d}$ and then AA $(100 \mathrm{ng} / \mathrm{ml})$ for $3 \mathrm{~d}$.

Pancreatic endocrine differentiation. Cells were cultured in MCDB-131 medium supplemented with $\mathrm{NaHCO}_{3}$ (2.5 g/liter), 1\% GlutaMAX, glucose (5.5 mM), 0.1\% FAF-BSA, and ITS:X (1:50,000), and were treated with Wnt3a $(20 \mathrm{ng} / \mathrm{ml})+\mathrm{AA}(100 \mathrm{ng} / \mathrm{ml})$ for $1 \mathrm{~d}$, AA (100 ng/ml) for $3 \mathrm{~d}$, and FGF7 (50 ng/ml; PeproTech) for $2 \mathrm{~d}$. For further endocrine differentiation, cells were cultured in MCDB-131 medium supplemented with $\mathrm{NaHCO}_{3}$ (2.5 g/liter), 1\% GlutaMAX, glucose $(8 \mathrm{mM}), 2 \%$ FAF-BSA, and ITS:X (1:200), and treated for 4 d with FGF7 $(50 \mathrm{ng} / \mathrm{ml})+\operatorname{noggin}(100 \mathrm{ng} / \mathrm{ml})+$ retinoic acid $(2 \mu \mathrm{M}$; Sigma-Aldrich) + SANT-1 (0.25 $\mu \mathrm{M}$; Sigma-Aldrich) + AA (20 ng/ $\mathrm{ml})$; for $3 \mathrm{~d}$ with SANT-1 $(0.25 \mu \mathrm{M})+\mathrm{PdBu}(200 \mathrm{nM}$; EMD) + noggin $(100 \mathrm{ng} / \mathrm{ml})$; and for $4-6 \mathrm{~d}$ with noggin $(100 \mathrm{ng} / \mathrm{ml})+$ Alk5 inhibitor (1 $\mu \mathrm{M}$; Axxora).

Directed differentiations for the scorecard analyses were performed using the following previously published protocols (Gifford et al., 2013).

Ectoderm. Ectoderm differentiation was induced using A83-01 ( $2 \mu \mathrm{m}$; Tocris Bioscience), PNU 74654 ( $2 \mu \mathrm{m}$; Tocris Bioscience), Dorsomorphin ( $2 \mu \mathrm{m}$; Tocris Bioscience), and DMEM/F12 (Life Technologies) containing $15 \%$ knockout serum replacement (Life Technologies) for $4 \mathrm{~d}$.

Mesoderm. Mesoderm differentiation was induced in DMEM/ F12 (Life Technologies) and 0.5\% FBS (HyClone; GE Healthcare), with Activin A (100 ng/ml; R\&D Systems) for $1 \mathrm{~d}$, and subsequently induced with BMP4 (100 ng/ml; R\&D Systems), VEGF (100 ng/ml; R\&D Systems), and FGF2 (20 ng/ml; Millipore) for $3 \mathrm{~d}$.

Endoderm. Endoderm differentiation was induced in Advanced RPMI (Invitrogen) and 0.5\% FBS (HyClone), with Activin A (100 ng/ $\mathrm{ml}$; R\&D Systems) and $\mathrm{LiCl}(2 \mu \mathrm{g} / \mathrm{ml}$; R\&D Systems $)$ for $4 \mathrm{~d}$.

\section{Immunocytochemistry and quantification}

Cells were rinsed in PBS and fixed in 4\% PFA (Sigma-Aldrich) for 30 min. After the rinses, cells were blocked for $1 \mathrm{~h}$ at room temperature in 5\% donkey serum (Jackson ImmunoResearch Laboratories, Inc.) and $0.3 \%$ Triton X-100 in PBS. All primary antibody incubations were done overnight at $4{ }^{\circ} \mathrm{C}$ in blocking solution at a 1:500 dilution unless otherwise noted. Primary antibodies used in this study were: Oct4 (mouse; R\&D Systems), Sox1 (goat; R\&D Systems), Pax6 (rabbit; Covance), Brachyury (goat; R\&D Systems), Sox17 (goat; R\&D Systems), Pdx1 (goat; R\&D Systems), Nkx6.1 (mouse; University of Iowa, Developmental Hybridoma Bank), Ngn3 (sheep; R\&D Systems), C-peptide (rat; Developmental Studies Hybridoma Bank), pRb 780 (1:350; $\mathrm{Rb}$ phosphorylation at Ser780; rabbit; Cell Signaling Technology), and underphosphorylated $\mathrm{Rb}$ (1:100; mouse; $\mathrm{BD})$. Cells were rinsed the next day, followed by secondary antibody incubation for $1 \mathrm{~h}$ at room temperature at a 1:500 dilution. Secondary antibodies (Invitrogen) conjugated to Alexa Fluor 488 or 594 were used to visualize primary antibodies. After PBS rinses, all nuclei were visualized by staining with Hoechst 33342 (1:1,000; Invitrogen).

Image acquisition and quantification. Immunofluorescent images were taken using a microscope (Observer.D1; Carl Zeiss) using an LD A-Plan 10×/0.25 NA Ph1 M27 objective lens with the DAPI,
GFP, or Texas red fluorochromes. Cells were imaged in PBS at room temperature, and images were acquired using the microscopy camera Axiom 503 mono(D) with the acquisition software AxioVision Rel 4.7 (Carl Zeiss). For quantification analyses, $3010 \times$ fields per well were acquired and quantified using a high-content screening system (ArrayScan VTI; Cellomics Technology). Cells labeled by antibody staining and total cell number (based on DAPI nuclei staining) were quantified to obtain percentages of target cell types.

\section{Flow cytometry}

For intracellular antibody staining, cells were fixed in 4\% PFA for 20 min at $4{ }^{\circ} \mathrm{C}$ followed by two PBS washes. Cells were resuspended in blocking solution consisting of 5\% donkey serum and $0.3 \%$ Triton $\mathrm{X}-100$ in PBS. Cells were then incubated for $30 \mathrm{~min}$ at $4^{\circ} \mathrm{C}$ with primary antibody RbAP46/48 (1:500; rabbit; Active Motif North America) or Ki67 (1:500; rabbit; Abcam) and washed twice in PBS. Last, cells were incubated with secondary antibody donkey anti-rabbit Alexa Fluor 594 (1:500; Invitrogen) for $30 \mathrm{~min}$ at $4^{\circ} \mathrm{C}$ and washed twice before assessment on a flow cytometer (LSRII FACS; BD) and analysis using the FlowJo software.

\section{Annexin V-propidium iodide staining}

Cells were harvested with TrypLE Express (Invitrogen), washed with cold PBS, and resuspended with annexin-binding buffer (50 $\mathrm{mM}$ Hepes, $700 \mathrm{mM} \mathrm{NaCl}$, and $12.5 \mathrm{mM} \mathrm{CaCl}_{2}, \mathrm{pH}$ 7.4) to a final concentration of $10^{6} \mathrm{cells} / \mathrm{ml} .5 \mu \mathrm{l}$ of Annexin V Alexa Fluor 488 conjugate (Molecular Probes) and $1 \mu \mathrm{l}$ of $100 \mu \mathrm{g} / \mathrm{ml}$ propidium iodide (Molecular Probes) were added per $100 \mu \mathrm{l}$ of cell suspension. After $15 \mathrm{~min}$ of incubation at room temperature, $400 \mu \mathrm{l}$ of annexin-binding buffer was added per $100 \mu \mathrm{l}$ of cell suspension. Samples were mixed gently and left on ice until analysis. Cells were assessed with a flow cytometer (LSRII FACS; BD) and analyzed using FlowJo software.

\section{Western blot analysis}

Cells were lysed using the RIPA lysis buffer (Santa Cruz Biotechnology, Inc.). Proteins were separated by 7.5\% SDS-PAGE (Bio-Rad Laboratories) and transferred to nitrocellulose membranes (Bio-Rad Laboratories). The membranes were blocked in 3\% BSA in $0.1 \%$ Tween 20 TBS for $1 \mathrm{~h}$ at room temperature and then incubated with the following primary antibodies overnight at $4^{\circ} \mathrm{C}$ : $\operatorname{Src}(47405 ; 1: 1,000$; rabbit; Abcam), Src (16885; 1:1,000; mouse; Abcam), ppRb (G3-245; 1:1,000; mouse; BD), underphosphorylated Rb (G99-549; 1:1,000; mouse; BD), or GAPDH (MAB374; 1:1,000; mouse; Millipore) as the loading control. After washing, the membranes were incubated with secondary antibodies for $1 \mathrm{~h}$ at room temperature: anti-mouse HRP (1:3,000; Cell Signaling Technology) or anti-rabbit HRP (1:5,000; Cell Signaling Technology), and then incubated in chemiluminescent HRP substrate (Millipore) for signal detection and development.

\section{RNA isolation and gene expression analyses by real-time PCR}

Total RNAs were isolated from purified cells of untreated and PP1treated hPSCs using the RNeasy mini kit (QIAGEN) and reverse transcribed using Superscript III RT (Invitrogen), according to the manufacturer's instructions. Real-time qPCR reactions were analyzed with a Mastercycler realplex 4 Sequence Detector (Eppendorf) via SYBR green (QuantitectTM SYBR Green PCR kit; QIAGEN). The relative gene expression level of each sample was expressed as a relative quantitation (RQ) value determined by the $2-$ ddCT method that represents the fold change in gene expression normalized to the housekeeping gene, GAPDH. The relative gene expression level of each sample was also compared with an internal control, i.e., untreated hPSCs. Complementary DNA PCR primer sequences are shown in Table S1. 


\section{qPCR and Scorecard analysis}

Total RNA was extracted from frozen cell pellets using Ambion Pure Link RNA Mini kit (Life Technologies). Eight cDNA reactions were set up from $1 \mu \mathrm{g}$ of total RNA per sample using a High-Capacity cDNA RT kit (Life Technologies). qPCR was performed on 384-well TaqMan hPSC Scorecard plates using Viia7 RUO software and a ViiA7 instrument (Applied Biosystems). Data were normalized to the mean expression level of five control genes that are highly invariant in expression during directed differentiation. Differentiation potential was calculated (Bock et al., 2011) for four gene classes (EC, ectoderm; ME, mesoderm; EN, endoderm; PP, pluripotent).

\section{Cell cycle analysis}

Cells were trypsinized and fixed in 4\% PFA for $20 \mathrm{~min}$ on ice and stained with Hoechst $33342(5 \mu \mathrm{g} / \mathrm{ml}$; Invitrogen $)$ in PBS for $30 \mathrm{~min}$. Equal numbers of cells were assessed for each cell line on a flow cytometer (LSRII FACS; BD) and analyzed using FlowJo software.

\section{Statistical analysis}

For statistical comparisons, mean values of two or more independent experiments were subjected to unpaired two-tailed Student's $t$ tests. P-values $\leq 0.05$ were considered significant.

\section{Online supplemental material}

Fig. S1 shows cell viability after the PP1 treatment. Fig. S2 shows how various cell cycle inhibitors regulate the differentiation potential of hPSCs. Fig. S3 shows the cell cycle profiles of several cell lines after the PP1 treatment. Fig. S4 shows how PP1 enhances the differentiation potential across all germ layers using various directed differentiation protocols. Fig. S5 shows that the initial PP1 treatment has positive impacts on terminal differentiation and provides benefits on differentiation capacity when combined with a DMSO treatment. Table S1 includes primer sequences used in the study. Online supplemental material is available at http://www.jcb.org/cgi/content/full/jcb.201502035/DC1.

\section{Acknowledgments}

We thank Lydia Gold, Veronika Akopian, and Ameen Chaudry for their excellent technical support, and Barak Blum, Jose Rivera-Feliciano, and Kristin Narayan for their helpful feedback on the manuscript. We also thank the Flow Cytometry Core facilities for their assistance.

This work was supported by grants from the Harvard Stem Cell Institute, the US National Institutes of Health (1R24DK092758 and IU01HL10040804), and the Leona M. and Harry B. Helmsley Charitable Trust.

The authors declare no competing financial interests.

Submitted: 9 February 2015

Accepted: 20 August 2015

\section{References}

Annerén, C., C.A. Cowan, and D.A. Melton. 2004. The Src family of tyrosine kinases is important for embryonic stem cell self-renewal. J. Biol. Chem. 279:31590-31598. http://dx.doi.org/10.1074/jbc.M403547200

Bain, J., L. Plater, M. Elliott, N. Shpiro, C.J. Hastie, H. McLauchlan, I. Klevernic, J.S.C. Arthur, D.R. Alessi, and P. Cohen. 2007. The selectivity of protein kinase inhibitors: a further update. Biochem. J. 408:297-315. http:// dx.doi.org/10.1042/BJ20070797
Ben-David, U., and N. Benvenisty. 2011. The tumorigenicity of human embryonic and induced pluripotent stem cells. Nat. Rev. Cancer. 11:268-277. http://dx.doi.org/10.1038/nrc3034

Bock, C., E. Kiskinis, G. Verstappen, H. Gu, G. Boulting, Z.D. Smith, M. Ziller, G.F. Croft, M.W. Amoroso, D.H. Oakley, et al. 2011. Reference Maps of human ES and iPS cell variation enable high-throughput characterization of pluripotent cell lines. Cell. 144:439-452. http://dx.doi.org/10.1016/j. cell.2010.12.032

Boulting, G.L., E. Kiskinis, G.F. Croft, M.W. Amoroso, D.H. Oakley, B.J. Wainger, D.J. Williams, D.J. Kahler, M. Yamaki, L. Davidow, et al. 2011. A functionally characterized test set of human induced pluripotent stem cells. Nat. Biotechnol. 29:279-286. http://dx.doi.org/10.1038/ nbt. 1783

Buchkovich, K., L.A. Duffy, and E. Harlow. 1989. The retinoblastoma protein is phosphorylated during specific phases of the cell cycle. Cell. 58:10971105. http://dx.doi.org/10.1016/0092-8674(89)90508-4

Chen, P.L., P. Scully, J.Y. Shew, J.Y. Wang, and W.H. Lee. 1989. Phosphorylation of the retinoblastoma gene product is modulated during the cell cycle and cellular differentiation. Cell. 58:1193-1198. http://dx.doi. org/10.1016/0092-8674(89)90517-5

Chetty, S., F.W. Pagliuca, C. Honore, A. Kweudjeu, A. Rezania, and D.A. Melton. 2013. A simple tool to improve pluripotent stem cell differentiation. Nat. Methods. 10:553-556. http://dx.doi.org/10.1038/nmeth.2442

Cowan, C.A., I. Klimanskaya, J. McMahon, J. Atienza, J. Witmyer, J.P. Zucker, S. Wang, C.C. Morton, A.P. McMahon, D. Powers, and D.A. Melton. 2004. Derivation of embryonic stem-cell lines from human blastocysts. N. Engl. J. Med. 350:1353-1356. http://dx.doi.org/10.1056/ NEJMsr040330

Edgar, B.A., and C.F. Lehner. 1996. Developmental control of cell cycle regulators: a fly's perspective. Science. 274:1646-1652. http://dx.doi. org/10.1126/science.274.5293.1646

Frame, M.C. 2002. Src in cancer: deregulation and consequences for cell behaviour. Biochim. Biophys. Acta. 1602:114-130.

Frederick, D.L., and M.T. Andrews. 1994. Cell cycle remodeling requires cellcell interactions in developing Xenopus embryos. J. Exp. Zool. 270:410416. http://dx.doi.org/10.1002/jez.1402700411

Gage, B.K., T.D. Webber, and T.J. Kieffer. 2013. Initial cell seeding density influences pancreatic endocrine development during in vitro differentiation of human embryonic stem cells. PLoS ONE. 8:e82076. http://dx.doi. org/10.1371/journal.pone.0082076

Gifford, C.A., M.J. Ziller, H. Gu, C. Trapnell, J. Donaghey, A. Tsankov, A.K. Shalek, D.R. Kelley, A.A. Shishkin, R. Issner, et al. 2013. Transcriptional and epigenetic dynamics during specification of human embryonic stem cells. Cell. 153:1149-1163. http://dx.doi.org/10.1016/j. cell.2013.04.037

Hanke, J.H., J.P. Gardner, R.L. Dow, P.S. Changelian, W.H. Brissette, E.J. Weringer, B.A. Pollok, and P.A. Connelly. 1996. Discovery of a novel, potent, and Src family-selective tyrosine kinase inhibitor. Study of Lck- and FynT-dependent T cell activation. J. Biol. Chem. 271:695-701. http://dx.doi.org/10.1074/jbc.271.2.695

Harbour, J.W., and D.C. Dean. 2000. The Rb/E2F pathway: expanding roles and emerging paradigms. Genes Dev. 14:2393-2409. http://dx.doi. org/10.1101/gad.813200

Hartwell, L.H., and T.A. Weinert. 1989. Checkpoints: controls that ensure the order of cell cycle events. Science. 246:629-634. http://dx.doi. org/10.1126/science.2683079

Imamoto, A., and P. Soriano. 1993. Disruption of the csk gene, encoding a negative regulator of Src family tyrosine kinases, leads to neural tube defects and embryonic lethality in mice. Cell. 73:1117-1124. http://dx.doi. org/10.1016/0092-8674(93)90641-3

Kim, L.C., L. Song, and E.B. Haura. 2009. Src kinases as therapeutic targets for cancer. Nat. Rev. Clin. Oncol. 6:587-595. http://dx.doi.org/10.1038/ nrclinonc.2009.129

Li, V.C., and M.W. Kirschner. 2014. Molecular ties between the cell cycle and differentiation in embryonic stem cells. Proc. Natl. Acad. Sci. USA. 111:9503-9508. http://dx.doi.org/10.1073/pnas.1408638111

Livingston, B.T., C.E. VanWinkle, and W.H. Kinsey. 1998. Protein tyrosine kinase activity following fertilization is required to complete gastrulation, but not for initial differentiation of endoderm and mesoderm in the sea urchin embryo. Dev. Biol. 193:90-99. http://dx.doi.org/10.1006/ dbio. 1997.8743

Murray, A.W., and M.W. Kirschner. 1989. Cyclin synthesis drives the early embryonic cell cycle. Nature. 339:275-280. http://dx.doi.org/10 $1038 / 339275 \mathrm{a} 0$ 
Orford, K.W., and D.T. Scadden. 2008. Deconstructing stem cell self-renewal: genetic insights into cell-cycle regulation. Nat. Rev. Genet. 9:115-128. http://dx.doi.org/10.1038/nrg2269

Osafune, K., L. Caron, M. Borowiak, R.J. Martinez, C.S. Fitz-Gerald, Y. Sato, C.A. Cowan, K.R. Chien, and D.A. Melton. 2008. Marked differences in differentiation propensity among human embryonic stem cell lines. Nat. Biotechnol. 26:313-315. http://dx.doi.org/10.1038/nbt1383

Pauklin, S., and L. Vallier. 2013. The cell-cycle state of stem cells determines cell fate propensity. Cell. 155:135-147. http://dx.doi.org/10.1016/j. cell.2013.08.031

Playford, M.P., and M.D. Schaller. 2004. The interplay between Src and integrins in normal and tumor biology. Oncogene. 23:7928-7946. http://dx.doi. org/10.1038/sj.onc. 1208080

Scott, R.E., D.L. Florine, J.J. Wille Jr., and K. Yun. 1982. Coupling of growth arrest and differentiation at a distinct state in the G1 phase of the cell cycle: GD. Proc. Natl. Acad. Sci. USA. 79:845-849. http://dx.doi.org/10.1073/ pnas.79.3.845

Segawa, Y., H. Suga, N. Iwabe, C. Oneyama, T. Akagi, T. Miyata, and M. Okada 2006. Functional development of Src tyrosine kinases during evolution from a unicellular ancestor to multicellular animals. Proc. Natl. Acad. Sci. USA. 103:12021-12026. http://dx.doi.org/10.1073/pnas.0600021103

Sela, Y., N. Molotski, S. Golan, J. Itskovitz-Eldor, and Y. Soen. 2012. Human embryonic stem cells exhibit increased propensity to differentiate during the G1 phase prior to phosphorylation of retinoblastoma protein. Stem Cells. 30:1097-1108. http://dx.doi.org/10.1002/stem.1078

Singh, A.M., J. Chappell, R. Trost, L. Lin, T. Wang, J. Tang, B.K. Matlock, K.P. Weller, H. Wu, S. Zhao, et al. 2013. Cell-cycle control of devel- opmentally regulated transcription factors accounts for heterogeneity in human pluripotent cells. Stem Cell Reports. 1:532-544. (published erratum appears in Stem Cell Reports. 2014. 2:398) http://dx.doi. org/10.1016/j.stemcr.2013.10.009

Smith, A.G. 2001. Embryo-derived stem cells: of mice and men. Annu. Rev. Cell Dev. Biol. 17:435-462. http://dx.doi.org/10.1146/annurev. cellbio.17.1.435

Tabar, V., and L. Studer. 2014. Pluripotent stem cells in regenerative medicine: challenges and recent progress. Nat. Rev. Genet. 15:82-92. http://dx.doi. org/10.1038/nrg3563

Takashima, Y., G. Guo, R. Loos, J. Nichols, G. Ficz, F. Krueger, D. Oxley, F. Santos, J. Clarke, W. Mansfield, et al. 2014. Resetting transcription factor control circuitry toward ground-state pluripotency in human. Cell. 158:1254-1269. http://dx.doi.org/10.1016/j.cell.2014.08.029

Taylor-Harding, B., U.K. Binné, M. Korenjak, A. Brehm, and N.J. Dyson. 2004 $\mathrm{p} 55$, the Drosophila ortholog of RbAp46/RbAp48, is required for the repression of dE2F2/RBF-regulated genes. Mol. Cell. Biol. 24:9124-9136. http://dx.doi.org/10.1128/MCB.24.20.9124-9136.2004

Toyoshima, H., and T. Hunter. 1994. p27, a novel inhibitor of G1 cyclin-Cdk protein kinase activity, is related to p21. Cell. 78:67-74. http://dx.doi org/10.1016/0092-8674(94)90573-8

Trelstad, R.L., E.D. Hay, and J.D. Revel. 1967. Cell contact during early morphogenesis in the chick embryo. Dev. Biol. 16:78-106. http://dx.doi. org/10.1016/0012-1606(67)90018-8

Zhu, S., H. Wurdak, J. Wang, C.A. Lyssiotis, E.C. Peters, C.Y. Cho, X. Wu, and P.G. Schultz. 2009. A small molecule primes embryonic stem cells for differentiation. Cell Stem Cell. 4:416-426. http://dx.doi.org/10.1016/j. stem.2009.04.001 